УДК 069.12: 374.1(477)

Олексій Караманов,

кандидат педагогічних наук, дочент кафедри загальної та сочіальної педагогіки Львівського начіонального університету імені Івана Франка

\title{
ОРГАНІЗАЦІЯ ПЕДАГОГІЧНО-ПРОСВІТНИЦЬКОЇ ДІЯЛЬНОСТІ МУЗЕЇВ У ВЗАЕМОДІЇ ІЗ ЗАКЛАДАМИ ПОЗАШКІЛЬНОЇ ОСВІТИ В УКРАЇНІ
}

У статті розглянуто особливості організащіі педагогічнопросвітницької діяльності музеїв в системі позашкільної освіти України, проаналізовано можсливості музейного та позашкільного освітнього простору у творчому розвитку, самореалізаиії та соціалізачиї дитини. Визначено різні форми $i$ напрями співпрачі музеїв із закладами позашкільної освіти, низку соиіально-педагогічних моделей, які успішно функиіонують у взаємодії із музеями.

Узагальнено сочіальні аспекти та перспективи педагогічнопросвітницької діяльності музеїв для забезпечення реалізачії компетентнісного підходу $i$ гуманізаиіі позашкільного освітньо-виховного простору.

Ключові слова: музей, заклади позашкільної освіти, педагогічнопросвітницька діяльність, співпрачя, сочіально-педагогічні моделі, компетентнісний підхід, гуманізація.

The author analyzes the peculiarities of the organization of educational and pedagogical activity of museums in the system of extracurricular education of Ukraine, as well as the possibilities of the museum and out-of-school educational space in the creative development, self-realization and socialization of children.

The article defines different forms and directions of cooperation of museums with institutions of extracurricular education (organization of clubs for reconstruction, activity of school museums, organization of museum studios, design of museum quests and museum routes, distribution of dramatized performances and performances in museum space, designing of various virtual objects, etc.), emphasizing the special interaction of the museum space (as a unique synthesis of art and culture) and out-of-school educational space (as an organized and structured social environment).

In this regard, the author refers to a number of socio-pedagogical models that successfully operate in conjunction with museums («Extracurricular 
educational institution as compensatory and educational space», «Extracurricular educational institution as a institution for the development of a creative person», "Extracurricular educational institution as child socialization establishment», "Extracurricular educational institution as a civic active institution», "Extracurricular educational institution as a center for educational and research activities of children and youth», "Extracurricular educational institution as a center of early profiling and pre-professional training»), as well as «School-museum-higher educational establishment».

In conclusion, the author summarizes the social aspects and prospects of pedagogical and educational activities of museums to ensure the implementation of a competent approach, humanization of extracurricular educational space.

Keywords: museum, institutions of extracurricular education, pedagogical and educational activities, cooperation, social pedagogical models, competence approach, humanization.

Розбудова сучасної системи позашкільних освітніх закладів в Україні неможлива без застосування різних інноваційних освітніх та педагогічних технологій, які узгоджують та стимулюють різноманітні соціокультурні зміни, що відбуваються у вітчизняному суспільстві. Ці зміни зумовлені певними реформами та новими вимогами, що передбачають урізноманітнення системи роботи позашкілля, підвищення уваги на характер та зміст організації дозвілля молоді, розширення предметних галузей пізнавальної діяльності, професійної орієнтації школярів для усвідомлення ними різних можливостей для особистісного розвитку та самовиховання.

Вищезазначене дозволяє стверджувати про важливість організації спільної діяльності закладів позашкільної освіти із закладами культури, зокрема, музеями, які мають потужний потенціал в організації просвітницької, ігрової, дослідницької, пошукової, рекреаційної та наукової діяльності. Така діяльність грунтується на засадах музейної педагогіки, яка дозволяє узгодити різні актуальні запити суспільства, об'єднати різних фахівців та аматорів, створити ефективне середовище навчання, виховання та комунікації.

Музейна педагогіка, як вагома частина позашкільної діяльності, являє собою логічно вибудуваний простір освіти, що забезпечує наскрізне вирішення педагогічних завдань на усіх етапах освітнього розвитку школярів і студентів в умовах вільного вибору [1, с. 12].

Мета нашої роботи - проаналізувати можливості та перспективи застосування педагогічно-просвітницької діяльності музеїв у системі роботи позашкільних закладів освіти України.

Порушена проблематика була предметом наукових досліджень: у загальному контексті розвитку позашкільної освіти - О. Биковської, 
В. Громового, А. Золотарьової, О. Литовченко, О. Мелентьєва, В. Міленіна, Г. Попової, Г. Пустовіта, Т. Свирської, Т. Сороки, Т. Сущенко, Н. Тверезовської та ін.; у контексті дозвіллєвої діяльності Н. Максимовської, І. Петрової; організації педагогічно-просвітницької роботи музеїв - Г. Вішиної, Л. Кірєєвої, С. Майко, В. Рибкіної, Н. Свиридової, які виокремлюють музейну педагогіку як важливий напрям розвитку системи додаткової освіти.

Забезпечення ефективної та дієвої співпраці закладів позашкільної освіти із музеями становить особливий інтерес як для теоретиків, так $\mathrm{i}$ практиків організації музейно-педагогічної діяльності. Така діяльність набуває особливого значення в умовах сьогодення, коли на порядок денний виходить не подання й відтворення готових знань, а творче осмислення, інтеграція та застосування навчального матеріалу; не проведення «беземоційних» академічних занять, а їх «оживлення» через різні прийоми, рівні та стратегії спілкування, об'єднання з інтересами учнів у площині неформальної освіти; не засвоєння сухого навчального матеріалу, а ознайомлення з яскравими наочними прикладами, які мають непересічне значення для особистісного розвитку дитини.

Саме такі можливості у контексті реалізації завдань позашкільної освіти створює музейний простір, - унікальний синтез творчих потенціалів мистецтва і культури, який наповнює новим змістом діяльність людини, що перебуває в ньому. Цей простір має виключне та особливе значення для розвитку пізнавальних здібностей дитини та узгоджується з позашкільним освітньо-виховним простором, що являє собою педагогічно організоване та структуроване соціально-освітнє середовище, спрямоване на творчий розвиток, самореалізацію та соціалізацію дітей і молоді [8, с. 53].

Відтак, спрямованість педагогічного процесу на розвиток творчої усебічно розвиненої особистості в дитячому колективі становить фундамент цілісного позашкільного педагогічного процесу [10, с. 70].

Зазначені положення узгоджуються із розумінням освіти як синтезу трьох важливих критеріїв. На думку відомого британського дослідника Б. Пітерса, це:

- освіта, яка передбачає передання свого ціннісного змісту тому, хто стає іï носієм;

- освіта, яка використовує таке знання й розуміння, а також таку когнітивну перспективу, які не є законсервованими;

- освіта, яка виключає деякі процедури передання знань i цінностей на тій основі, що вони не є повністю усвідомленими та добровільними [11, с. 45].

Власне, таке розуміння освіти 3 позиції усвідомлення іiі ціннісного змісту, когнітивної перспективи та можливостей добровільного опанування відповідає засадничим основам позашкільної діяльності, адже 
вона є важливим соціальним інститутом, який розвиває свою методику на засадах компетентнісного підходу, де у зміст освіти, зокрема, інтегровані такі компетентності особистості, як пізнавальна, практична, творча i соціальна [5].

На думку Г. Вішиної, взаємодія із закладами позашкільної освіти у системі «школа - музей - вищий заклад освіти» $\epsilon$ першочерговою умовою ефективного розвитку музейної педагогіки. Це сприяє їх взаємозбагаченню, стимулює вагомі навчальні та виховні ефекти за рахунок включення студентів та школярів у соціально значущі види діяльності, співтворчість, появу нових форм позакласної роботи, а також уможливлює підготовку музейного педагога (який поєднує функції учителя, наукового співробітника та педагога додаткової освіти) зі створення умов для його професійної педагогічної діяльності [2, с. 15-18].

Різні напрями просвітницької та педагогічної діяльності музеїв можуть бути реалізовані й втілені у відповідних формах діяльності музейних студіях, театральних школах і школах мистецтв, різноманітних гуртках, шкільних музеях тощо.

Шкільні музеї у контексті цієї діяльності посідають особливе місце, оскільки у сучасних умовах реформування освітньої галузі можуть виступати ефективним динамічним, інтерактивним освітнім простором, що $\epsilon$ ідеальним місцем для діалогу вчителя 3 учнем, творчої самореалізації молоді, коли учень $\epsilon$ активним споживачем i водночас творцем різноманітного музейного контенту.

Аналогічно й студентські музеї вищих закладів освіти пов'язані 3 традиціями позанавчальної діяльності, виконуючи одне 3 провідних завдань для студентської молоді - збереження традицій та уведення інновацій, коли самі студенти безпосередньо беруть участь у розбудові музейної експозиції, осучаснюють способи експонування та участі глядачів і відвідувачів, формують власні традиції, застосовуючи реальну та віртуальну музейну анімацію [6, с. 205].

Надаючи вагому інформацію про минуле та сучасність й сприяючи активній реалізації дозвілля, музей стимулює молодь до активного співробітництва, що втілюється в організації різних досліджень й популяризації його діяльності, залучення й проведення волонтерами акцій та екскурсій, виготовлення соціальної реклами тощо [6, с. 241].

Науковці переконливо доводять, що у процесі комунікації вихованця i педагога у межах позашкілля створюються комфортні та сприятливі умови для творчої діяльності, коли педагог виступає у ролі посередникаконсультанта, а його взаємодія 3 учнем стає повноцінним творчим процесом. Це важливо з огляду на розширення світогляду молодої людини, iї орієнтації на освоєння і розвиток світових культурних цінностей, набуття позитивного соціального досвіду самовдосконалення і реалізація своїх 
особистісних ресурсів [7, с. 9].

Серед актуальних напрямів співпраці музеїв із позашкіллям у розглянутому контексті можна відзначити, приміром:

- організацію клубів реконструкції («Аркона» (м. Вінниця), «Берсерк» (м. Чернівці), «Воин» (м. Запоріжжя), «Князь» (м. Харків), «Лицарі Великого степу» (м. Херсон), «Спадщина» (м. Київ), «Срібний вовк» (м. Львів), «Чорна Галич» (м. Львів) та ін.), які демонструють / відтворюють / відновлюють певний елемент матеріальної або нематеріальної культурної спадщини;

- роботу шкільних музеїв (шкільні музеї с. Колочава), шкільний музей ім. А. С. Макаренка (СЗШ № 34, м. Харків), шкільні музеї при СЗШ № 34 ім. М. Шашкевича, м. Львів, Етнографічний музей української родини (СЗШ № 3, м. Марганець), краєзнавчий музей «Оберіг» (Старопетрівська загальноосвітня школа, Київська область), Музей бойової слави (СЗШ № 1, м. Одеса) та ін.) - своєрідних дослідницьких регіональних центрів, що активно залучають школярів до краєзнавчої роботи та збереження місцевих традицій;

- діяльність музейних студій (дитячі музейні студії при Львівській Національній Галереї Мистецтв ім. Бориса Возницького та Музеї Івана Труша, «Коло ідей» - Національний музей народного мистецтва Гуцульщини у Коломиї, «Жива глина» - Дніпропетровський національний музей ім. Д. Яворницького, Музей-студія фотомистецтва - Хмельницький, Арт-студія «МуХа» - музей Ханенків у Києві та ін.), що заохочують дітей та молодь до різної інтелектуальної дозвіллєвої діяльності;

- проектування різноформатних «музейних квестів» та «музейних маршрутів» («едукаиійних стежок») (Дніпропетровський національний музей ім. Д. Яворницького, Історичний комплекс Національного музею у Львові ім. А. Шептицького, Музей Ханенків, Національний художній музей України, Одеський муніципальний музей особистих колекцій ім. А. Блещунова, Художньо-меморіальний музей I. Рєпіна та ін.), що об'єднують потенціал музеїв та навколомузейного простору - сукупності різноманітних архітектурних, мистецьких та туристичних об'єктів;

- поширення музейних театралізованих дійств, які встановлюють міцний емоційний зв'язок між відвідувачами у процесі осмислення минулого шляхом організації різноманітних вистав, майстер-класів, «ночі в музеях», літературно-музичних вечорів тощо (Волинський краєзнавчий музей, Національний Києво-Печерський історико-культурний заповідник, Національний музей історії України, Одеський муніципальний музей особистих колекцій ім. А. Блещунова, мобільний театр пісні «Левеня» (Львів) та ін.);

- конструювання віртуальних об 'єктів, які відображають особистісні інтерпретації молодою людиною реальних музейних предметів та історії 
видатних діячів минулого (Віртуальний музей Василя Стуса, Дніпропетровський національний історичний музей ім. Д. І. Яворницького, Музей Волинської ікони, Музей грошей Національного банку України, Музей скла у Львові та ін.).

Виходячи із вищенаведених напрямів, педагог позашкільної освіти у процесі організації музейно-педагогічної діяльності повинен обов'язково звертати увагу на те, щоби навчити дитину бачити історико-культурний

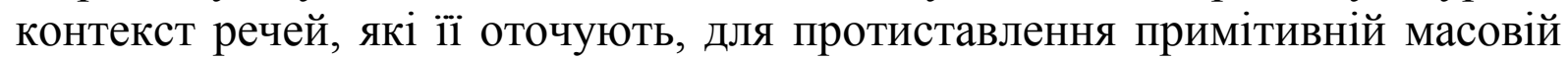
культурі; розуміти взаємозв'язок історичних епох і своєї причетності до певного часу та ідентичності сучасній культурі шляхом спілкування 3 пам'ятками історії та культури; формувати стійку потребу i навики спілкування з різними пам'ятками поряд із повагою до різних культур; розвивати здатність до естетичного споглядання, співпереживання та насолоди тощо [9].

Різноманітність системи позашкільних навчальних закладів в Україні дає змогу вивчати особливості їх педагогічно-просвітницької діяльності через низку прогностичних соціально-педагогічних моделей. Беручи за основу деякі з цих моделей, розроблених вітчизняними науковцями [2], спробуємо окреслити особливості їх функціонування та перспективи розвитку позашкільної діяльності у взаємодії з музеями.

Наприклад, вивчення моделі «Позашкільний навчальний заклад як компенсаторно-виховний простір» $[8$, с. 84] дозволяє висунути припущення, що музеї як заклади культури можуть відігравати вагому роль у роботі позашкільних закладів 3 вирішення різноманітних соціальних проблем у місцевому соціокультурному просторі у сенсі створення умов для комунікативно-творчої реалізації особистості, забезпечення ефективної діяльності освітньо-виховних систем профільних гуртків, музейних студій, клубів реконструкцій.

Очевидним є зв'язок педагогічно-просвітницької діяльності музеїв із моделлю «Позашкільний навчальний заклад як заклад розвитку творчої особистості» [8, с. 85], адже музеї здатні створювати ефективне позашкільне освітньо-виховне середовище (у форматі взаємодії музейного та навколомузейного простору), орієнтоване на розвиток природних задатків і здібностей дітей та молоді, креативності, розширення їх соціального досвіду та формування відповідних рис характеру.

Модель «Позашкільний навчальний заклад як заклад соціалізації дитини» [8, с. 87] має виключне значення для організації педагогічнопросвітницької діяльності музеїв, адже саме у процесі споглядання та взаємодії з музейним предметом у дитини виникає ефект співпричетності до нього, «занурення» до певної історичної епохи та нове розуміння іiі значення, трансформація цього розуміння у дійсність [3, с. 60-62]. Такий перехід визначають нові умови, які оточують дитину (музейні предмети, 
урочиста атмосфера та взаємодія з іншими відвідувачами музею), що сприяє iї соціальній адаптації, соціально-творчій реабілітації, формуванню соціального досвіду.

У моделі «Позашкільний навчальний заклад як громадсько-активний заклад» [8, с.90] можна провести паралелі 3 вдало спроектованими музейними заняттями, семінарами, тренінгами, які стимулюють розвиток ініціативних громадян 3 розвинутими якостями самопрезентації, підприємництва, інноваційності. Здебільшого такі заняття заохочують до музеїв волонтерів різного віку, що сприяє соціальній активності вихованців, утвердженні демократичних цінностей, формуванню громадянських якостей особистості у процесі проведення квестів, благодійних акцій, організації різних музейних маршрутів тощо.

Серед інших викликають зацікавлення моделі «Позашкільний навчальний заклад як центр навчально-дослідної діяльності дітей та учнівської молоді» та «Позашкільний навчальний заклад як центр ранньої профілізації та допрофесійної підготовки» [8, с.91], які можуть бути спрямовані на широке залучення молодих людей до проектної роботи в музейному просторі (виконання різноманітних пошукових творчих завдань), а також участі у музейних профорієнтаційних заходах, коли про переваги тієї чи іншої професії може переконливо розповісти експозиція.

Таким чином, позашкільна освіта у контексті організації просвітницької та педагогічної діяльності музеїв відкриває можливості для:

- розвитку розумових здібностей дитини (у процесі конструювання нових умінь і навичок у просторі музею);

- формування відповідних емоцій (у ході створення ефектів «занурення» й «переживання» знань);

- організації колективної співтворчості (спільна продуктивна діяльність дітей з метою розв'язання проектних завдань у межах творчої пошукової діяльності, історичних реконструкцій, краєзнавчої роботи) тощо.

Виконуючи важливу соціальну роль, музеї у співпраці із закладами позашкільної освіти можуть виступати як школа візуального та просторового сприйняття; простір, що акумулює естетичний досвід дитини; своєрідний фільтр якості у ставленні дитини до навколишнього соціуму у предметному, філософському та естетичному розумінні; середовище, яке виховує та формує особливі норми поведінки, спілкування, обміну думками та враженнями, а також сприяє релаксації та відпочинку дитини [4, с. 23-24].

Утім, чи не «найважливішим завданням педагогів-позашкільників в умовах сьогодення $\epsilon$ така організація педагогічного процесу, за якої кожна дитина відчуває себе особистістю надзвичайно цікавою й потрібною колективу» [10, с. 132]. На нашу думку, це насамперед забезпечує 
реалізація компетентнісного підходу (як основа для майбутньої професійної діяльності, виконання різних соціальних ролей тощо) та гуманізація позашкільного освітньо-виховного простору (як основа для утвердження гуманних стосунків та ідей гуманізму у цій сфері).

Перспективами застосування педагогічної та просвітницької діяльності музеїв у взаємодії з позашкільними закладами освіти України можна визначити:

- по-перше, розширення та удосконалення меж, напрямів та форм роботи самих позашкільних навчальних закладів (шкільних музеїв, студій, клубів реконструкцій тощо), які забезпечують практичну спрямованість навчання і виховання особистості на засадах компетентнісного підходу;

- по-друге, проведення позашкільних заходів, спрямованих на формування музейної культури особистості, яка уможливлює розуміння дитиною музейної інформації та іiі уміння орієнтуватися у середовищі музею, розуміти мову музейної експозиції, сприймати музейний предмет у певному історико-культурному середовищі, оцінювати його як частинку власної історії;

- по-трете, активне використання соціально-педагогічних моделей з елементами музейної педагогіки (зокрема, у взаємозв'язку школи, музею, закладу позашкільної освіти та вищого закладу освіти) для формування позитивно спрямованого, оптимістичного життєвого досвіду особистості, яка сприймає процес соціалізації і може повноцінно застосовувати здобуті знання на практиці.

\section{СПИСОК ВИКОРИСТАНИХ ДЖЕРЕЛ}

1. Вишина Г. В. Музейная педагогика в структуре высшей и средней школы: монография. Воронеж: Научная книга, 2006. 184 с.

2. Вишина Г. В. Музейная педагогика как направление развития системы дополнительного образования: автореф. дис. ... канд. пед. наук: 13.00.01. Липецк, 1999. 20 с.

3. Караманов О. Роль музейної педагогіки у процесі соціалізації особистості. Вісник Львівського університету. Серія педагогічна. 2007. Вип. 22. С. 58-64.

4. Киреева Л.Н. Социально-воспитательная деятельность музея в условиях малого города: автореф. дис. ... канд. пед. наук: 13.00.02. Москва, 2003. 25 с.

5. Концепція позашкільної освіти. Проект. / Національний екологонатуралістичний центр учнівської молоді. URL: https://nenc.gov.ua/wpcontent/uploads/2017/12/pkpo.pdf (дата звернення: 25.07.2018).

6. Максимовська Н. О. Соціально-педагогічна діяльність зі студентською молоддю у сфері дозвілля: анімаційний підхід: монографія. Харків: Тім Пабліш Груп, 2015. 368 с. 
7. Попова Г. Д. Педагогічний потенціал системи позашкільної освіти. Наукові записки Наџіонального педагогічного університету ім. М. П. Драгоманова. Сер.: Педагогічні та історичні науки. 2014. Вип. 121. С. 190-196.

8. Крекотіна Т. М., Перепелиця Н. В., Сидоренко Н. Ю. Позашкільна освіта: теоретичні і практичні аспекти розвитку: у 3 кн.: монографія / за заг. ред. Л. В. Тихенко. Суми: Університетська книга, 2015. Кн. 1. $270 \mathrm{c}$.

9. Рыбкина Г. Н. Возможности музейной педагогики в дополнительном образовании детей / Дом детского творчества «Преображенский». URL: http://www.spb-ddt.ru/publ/publikacii_pedagogov/publikacii_pedagogov/ vozmozhnosti_muzejnoj_pedagogiki_v_dopolnitelnom_obrazovanii_detej/9-10-24 (дата звернення: 10.07.2018).

10. Сущенко Т. І. Позашкільна педагогіка: теорія, історія, практика: наук.метод. посібник. Київ: ТОВ «Праймдрук», 2011. 299 с.

11. Peters R. S. Ethic and Education. London: Allen and Urwin, 1966. 333 p. 